\title{
Effect of Hydrolysis Reaction Time on the Reducing Sugar Yield of Acha (Digitaria exilis) and Finger Millet (Eleusine coracana) Starch for Bioethanol Production
}

\author{
A U. OFOEFULE ${ }^{1 *}, \mathrm{U}^{\mathrm{C}}$. OKORO${ }^{2}$ and O D. ONUKWULI ${ }^{3}$ \\ ${ }^{1}$ Biomass Unit, National Center for Energy Research and Development, University of \\ Nigeria, Nsukka, Enugu state \\ ${ }^{2}$ Department of Pure \& Industrial Chemistry, University of Nigeria, Nsukka, Enugu state \\ ${ }^{3}$ Department of Chemical Engineering, Nnamdi Azikiwe University, Awka, Anambara state, \\ Nigeria \\ akuzuoo@yahoo.com
}

Received 10 November 2014 / Accepted 28 November 2014

\begin{abstract}
The effect of hydrolysis reaction time on the reducing sugar yield of Acha (Digitaria exilis) and Finger millet (Eleusine coracana) starch for bioethanol production was studied. The starches were extracted from the feedstocks by wet and dry milling methods. They were gelatinized at slurry concentrations of 2.0, 2.5, 3.0 and $3.5 \mathrm{~mL} / \mathrm{g}$ for Acha and slurry concentrations of 2.5, 3.0, 3.5 and $4.0 \mathrm{~mL} / \mathrm{g}$ for finger millet. They were then hydrolyzed using malted barley as enzyme at enzyme concentrations of $0.1 \mathrm{~g} / \mathrm{g}$ to $0.3 \mathrm{~g} / \mathrm{g}$ at durations ranging from $1 \frac{1}{2}-3 \frac{1}{2} \mathrm{~h}$. The results showed that for the two starches studied, none achieved highest reducing sugar yield at $1 \frac{1}{2}-2 \frac{1}{2} \mathrm{~h}$. The optimum fell largely between 3 to $3 \frac{1}{2} \mathrm{~h}$. Overall results indicate that reducing sugar quantity is largely dependent on slurry concentration $(\mathrm{mL} / \mathrm{g})$ of starch, hydrolysis reaction time and even temperature.
\end{abstract}

Keywords: Hydrolysis reaction time, Enzyme concentration, Reducing sugar yield, Bioethanol production, Finger millet, Acha

\section{Introduction}

The current trend in soaring oil prices, global warming and environmental pollution has encouraged major consumers worldwide to sharply increase their use of "green" fuels. Bioethanol is usually obtained from the conversion of carbon-based feedstock. Bioethanol from biomass sources is the principal fuel used as a petrol substitute for road transport vehicles ${ }^{1}$. Bioethanol is mainly produced by the sugar fermentation process although it can also be manufactured by the chemical process of reacting ethylene with steam. Acha (Digitaria exilis Kippis. stapf and Digitaria Iburua Kippis. stapf.) is known with other names such as fonio, findi, fundi, pom, kabuga, hungry rice and so forth in different West Africa countries $^{2}$. The crop is rugged and grows on poor and even acidic soils with high aluminum 
content, that are toxic to other crops ${ }^{3}$. It is one of the smallest cereals known. Acha is relatively drought-tolerant thus, it has potential in regions where low rainfall and irrigation expense present problems for the growth of crops ${ }^{4}$. Most feedstocks are relatively expensive for ethanol production and compete with human and animal consumption which, may lead to higher grain and sugar price in the future. The starch of this crop is found to be high in sugar yield which will translate to high ethanol yields. Because of lack of attention by research and extension services, the crop is undeveloped. While the brewing, malting and pharmaceutical properties of acha have been studied elsewhere, no documentation have been cited or found about making fermented/alcoholic beverage from acha ${ }^{5}$.

Finger millet (Eleusine coracana) is also known with other names such as Ragi (India), Kodo (Nepal), Uburo (Rwanda), Kurakkan (Srilanka) Bulo (Uganda), Kambale (Zambia) and Tamba (Nigeria) etc ${ }^{6}$. For all its importance, however, finger millet is grossly neglected both scientifically and internationally. Compared to the research lavished on wheat, rice and maize for instance, it receives almost none. Finger millet tolerates poor soils and low rainfall. It also lasts a very long time in storage. It is said to improve in quality with storage and can be stored without damage for as long as 50 years ${ }^{7}$. Reddy and Reddy ${ }^{8}$ reported the role of finger millet flour in the rapid and enhanced production of ethanol in very high gravity (VHG) sugar fermentation by Saccharomyces cerevisiae. It was found that the finger millet flour not only reduced the fermentation time (from 5 to 3 days) but also enhanced the ethanol concentration from 10 to $15 \%(\mathrm{v} / \mathrm{v})$ by better utilization of sugar. Anthony et al., reported the effect of fermentation on the primary nutrients in finger millet. The study revealed that fermentation decreased the starch and long chain fatty acids content. This study was undertaken to explore the effect of hydrolysis reaction time on the reducing sugar yield for the two starch feedstock Acha (Digitaria exilis) and Finger millet (Eleusine coracana) in order to ascertain the optimum time for highest sugar yield which will in effect impact on bioethanol yields.

\section{Experimental}

The acha grains and finger millet were procured from local markets in Nigeria. The malted barley utilized as the source of enzyme was obtained from Nigerian Breweries Plc, in Enugu state. The chemicals utilized for the reducing sugar measurements were procured from a local supplier and were used without further purification.

\section{Extraction of starch from acha and finger millet}

This extraction was carried out using a combination of dry and wet milling methods ${ }^{10}$. The acha grains $(3.68 \mathrm{~kg})$ were soaked for three (3) days while the finger millet $(3.65 \mathrm{~kg})$ was threshed several times using a tray to remove stones and other impurities. It was de-hulled using the traditional corn mill grinder. The de-hulled grains were washed with water and soaked for three days after which they were drained. The two starches were then milled with the traditional corn grinder. They were sieved with water using a muslin cloth. The starch-water mixtures were allowed to settle by gravity for some hours. The supernatant was decanted. The remaining starch with some quantity of water was poured into a cotton cloth bag, squeezed and pressed severally to expel the remaining water. The resulting starch lumps were broken into small pieces/bits and dried in a solar dryer for a period of five days. It was further dry-milled with an electronic blender to reduce the starch lumps to very fine powdery flour. The starch flour was again sieved with $0.25 \mu \mathrm{m}$ mesh to obtain the finest powdery starch. 


\section{Analyses of starch feedstock}

\section{Physicochemical analysis}

Moisture, ash, crude fibre and calorific value were determined using AOAC method ${ }^{11}$. Crude fat by soxhlet extraction, crude nitrogen/protein by micro- Kjeldahl were all determined by Pearson method ${ }^{12}$. Reducing sugar was determined qualitatively by Benedicts test for reducing sugars and quantitatively by the Plummer method ${ }^{13}$.

\section{Data analyses}

Statistical analysis was carried out on the data generated from the bioethanol hydrolysis using "Randomized Complete Block Design (RCBD)"; a two way analysis of variance (ANOVA) with repeated measures. This was carried out between parameters and between feedstocks using a combination of SPSS 17.0 version and Genstat 3.

\section{Gellatinization of the starch samples}

The gelatinization processes were carried out according to the method of Novellie and Shütte $^{14}$. For the acha starch, four sets of $100 \mathrm{~g}$ of acha starch were weighed out. To each of these four sets of $100 \mathrm{~g}$ of the starch, $200 \mathrm{~mL}, 250 \mathrm{~mL}, 300 \mathrm{~mL}$ and $350 \mathrm{~mL}$ of distilled water (representing slurry concentrations of 2.0, 2.5, 3.0 and $3.5 \mathrm{~mL} / \mathrm{g}$ ) was added respectively. For the finger millet, four sets of $100 \mathrm{~g}$ of finger millet starch were weighed and added to $250 \mathrm{~mL}, 300 \mathrm{~mL}, 350 \mathrm{~mL}$ and $400 \mathrm{~mL}$ of distilled water (representing slurry concentrations of $2.5,3.0,3.5$ and $4.0 \mathrm{~mL} / \mathrm{g}$ ) respectively. They were heated over water bath till gel formations took place and the gellation temperature noted.

\section{Hydrolysis of the starches}

The gelatinized acha and finger millet starches using the different quantities of water were cooled and equilibrated at ambient temperature $\left(30^{\circ} \mathrm{C}\right)$. In each case $10 \mathrm{~g}, 20 \mathrm{~g}$ and $30 \mathrm{~g}$ of powdered malted barley were weighed into $250 \mathrm{~mL}$ conical flasks containing $50 \mathrm{~mL}$, $100 \mathrm{~mL}$ and $150 \mathrm{~mL}$ of distilled water, respectively. These were stirred very well and added into the two separately gelatinized acha and finger millet which were contained in $1000 \mathrm{~mL}$ beakers. The temperature of the water bath was increased and maintained constant between $40-50{ }^{\circ} \mathrm{C}$ which is the temperature range for the activation of $\alpha$-amylase. The temperature of the water bath was allowed to remain constant within this range for one hour. It was then raised to $65-70{ }^{\circ} \mathrm{C}$ range, another temperature range that helps the activation of $\beta$-amylase and glucosidase. The mixtures were stirred at intervals of $20 \mathrm{~min}$ for a total of $3 \frac{1 / 2}{\mathrm{~h}}$. Aliquots were withdrawn from the solution at $1 \frac{1}{2} \mathrm{~h}, 2 \mathrm{~h}, 2 \frac{1}{2} \mathrm{~h}, 3 \mathrm{~h}$ and $3 \frac{1}{2} \mathrm{~h}$ intervals and in some instance $4 \mathrm{~h}$. They were tested for reducing sugar qualitatively and quantitatively. The quantities of reducing sugar produced at each interval were noted.

\section{Results and Discussion}

For the acha starch, there was a general increase in the yield of reducing sugar with time across board for all the variants. Among the different water contents, the reducing sugar yield peaked at $2.0 \mathrm{~mL} / \mathrm{g}$ with $0.3 \mathrm{~g} / \mathrm{g}$ of enzyme concentration at $31 / 2 \mathrm{~h}$ (Figure 1). For the $2.0 \mathrm{~mL} / \mathrm{g}$, there was no significant increase in sugar yield between the 0.1 and $0.2 \mathrm{~g} / \mathrm{g}$ enzyme concentration $(\mathrm{P}>0.05 \%)$ at $1 \frac{1}{2}-2 \frac{1}{2} \mathrm{~h}$. However, from $3 \mathrm{~h}$ to $3 \frac{1}{2} \mathrm{~h}$ there was significant increase $(\mathrm{P}<0.05 \%)$ with the highest yield at $3 \frac{1}{2} \mathrm{~h}$. For the $2.5 \mathrm{~mL} / \mathrm{g}$, the trend followed with slight difference in $0.1 \mathrm{~g} / \mathrm{g}$ (at $3 \mathrm{~h}$ ). The highest value for sugar yield obtained for that water content was at $31 / 2 \mathrm{~h}(0.3 \mathrm{~g} / \mathrm{g}$ enzyme concentration). For the $3.0 \mathrm{~mL} / \mathrm{g}$, there was no significant difference between the $0.1 \mathrm{~g} / \mathrm{g}$ and $0.2 \mathrm{~g} / \mathrm{g}$ at $31 / 2 \mathrm{~h}$. The highest value was obtained at $31 / 2 \mathrm{~h}(0.3 \mathrm{~g} / \mathrm{g}$ enzyme concentration $)$. For the $3.5 \mathrm{~mL} / \mathrm{g}$, the trend persisted. 
There was no significant difference between the reducing sugar yields at $1 \frac{1}{2}-2 \frac{1}{2} \mathrm{~h}$. The optimum value was obtained at $3 \mathrm{~h}(0.2 \mathrm{~g} / \mathrm{g}$ enzyme concentration), which was the same value for $0.3 \mathrm{~g} / \mathrm{g}$ at $3 \mathrm{~h}$. General result for acha starch indicates that after $2.0 \mathrm{~mL} / \mathrm{g}$ the reducing sugar yield reduced generally and remained at $125 \mathrm{mg} / \mathrm{mL}$ till the $3.5 \mathrm{~mL} / \mathrm{g}$. Optimum reaction time was at $3 \frac{1}{2} \mathrm{~h}$ (with $0.3 \mathrm{~g} / \mathrm{g}$ enzyme concentration), at $2.0 \mathrm{~mL} / \mathrm{g}$ water content to achieve a reducing sugar yield of $238.10 \mathrm{mg} / \mathrm{mL}$.
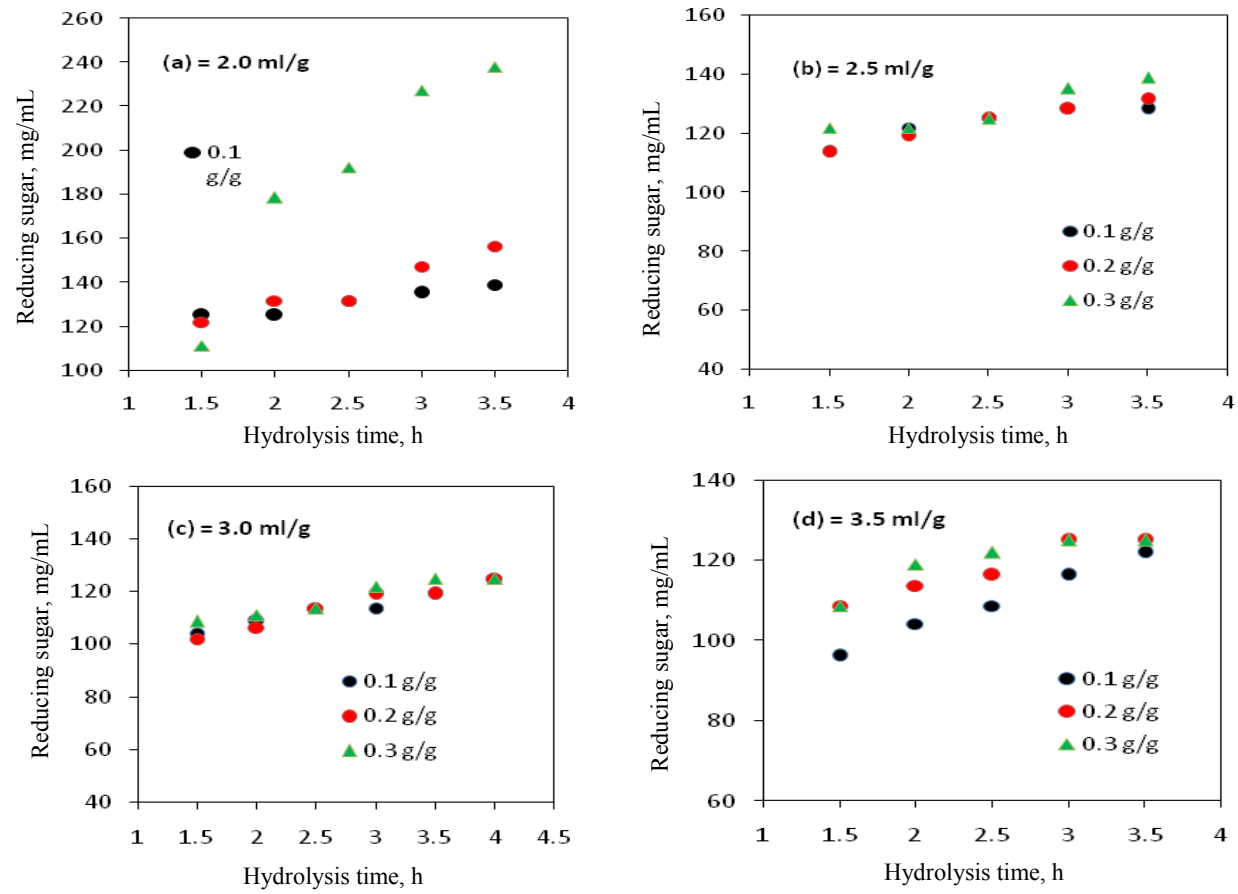

Figure 1. Hydrolysis profile for acha

\section{Finger millet}

For the finger millet, the yield of reducing sugar also generally increased with increase in reaction time across board for all the variants. Among the different water contents, the sugar yield peaked at $3.0 \mathrm{~mL} / \mathrm{g}$ with $0.2 \mathrm{~g} / \mathrm{g}$ of enzyme concentration at $3 \mathrm{~h}$. Above this water content, there was a gradual reduction till the last variant (Figure 2). For the $2.5 \mathrm{~mL} / \mathrm{g}$, there was no significant difference between the reducing sugar yield from $1 \frac{1}{2}-2 \frac{1}{2} \mathrm{~h}(\mathrm{P}>0.05 \%)$. From $3 \mathrm{~h}$, there was significant difference in the sugar yields and the highest yield was obtained at $3 \mathrm{~h}(0.3 \mathrm{~g} / \mathrm{g}$ enzyme concentration). For the $3.0 \mathrm{~mL} / \mathrm{g}$, the trend was repeated and the highest sugar yield was obtained at $3 \mathrm{~h}(0.2 \mathrm{~g} / \mathrm{g}$ enzyme concentration). The same value was also obtained for $3 \mathrm{~h}(0.3 \mathrm{~g} / \mathrm{g})$. Cost considerations suggest that $3 \mathrm{~h}(0.2 \mathrm{~g} / \mathrm{g})$ is the optimum. For the $3.5 \mathrm{~mL} / \mathrm{g}$, the optimum sugar yield was obtained at $3 \frac{1}{2} \mathrm{~h}(0.3 \mathrm{~g} / \mathrm{g}$ enzyme concentration), while for the $4.0 \mathrm{~mL} / \mathrm{g}$ water content, the optimum yield was obtained at two levels; $3 \frac{1}{2} \mathrm{~h}(0.2 \mathrm{~g} / \mathrm{g})$ and $3 \mathrm{~h}(0.3 \mathrm{~g} / \mathrm{g})$. The choice of which variant to use would then depend on the availability of materials and prevailing situations on ground. General results for finger millet indicate that the reducing sugar yield decreased with increase in water content (after $3.0 \mathrm{~mL} / \mathrm{g}$ ). Again optimum conditions arrived at was; $3 \mathrm{~h}$ using $0.2 \mathrm{~g} / \mathrm{g}$ of enzyme concentration with $3.0 \mathrm{~mL} / \mathrm{g}$ water content to give reducing sugar yield of $125 \mathrm{mg} / \mathrm{mL}$. 

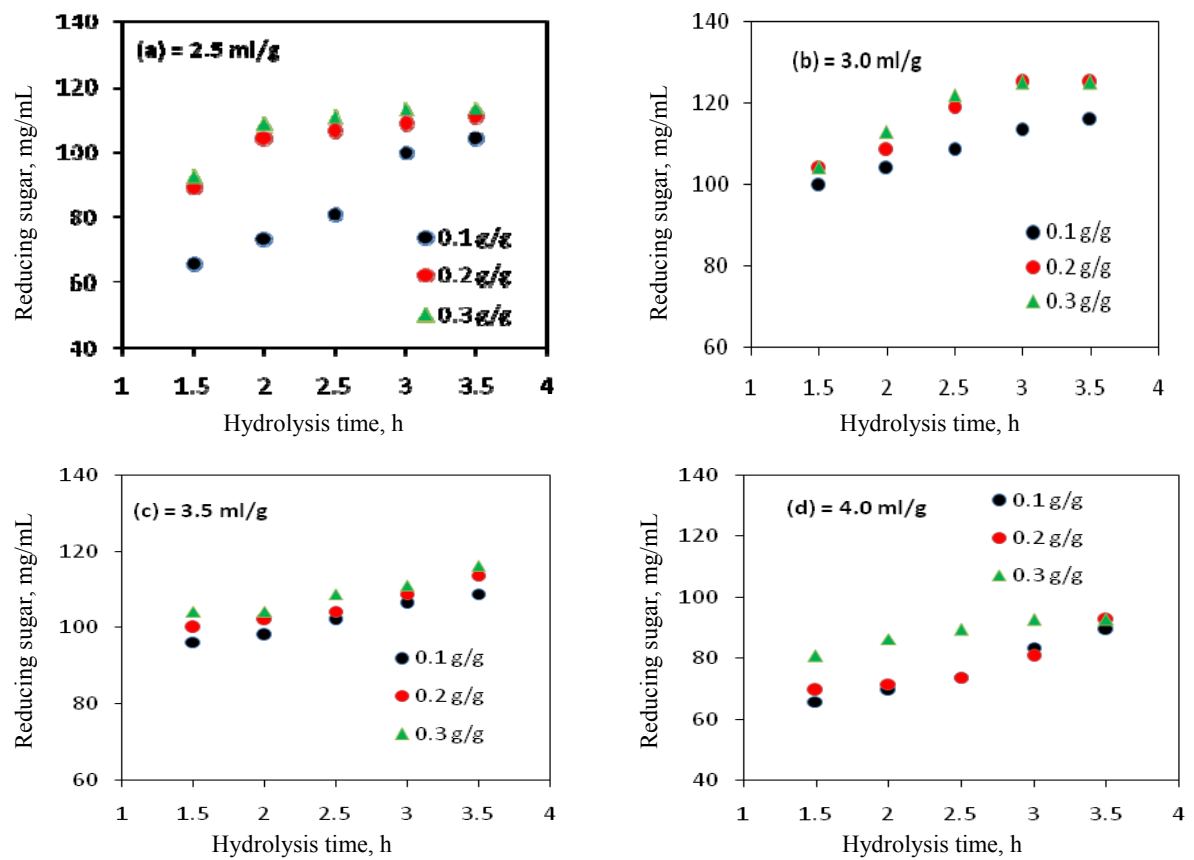

Figure 2. Hydrolysis profile for finger millet

The reasons for the little or no significant difference between $1 \frac{1}{2}-2 \frac{1}{2} \mathrm{~h}$ reaction times for most of the variants (water content and enzyme concentration) can be attributed to the fact that the three enzymes for hydrolysis of starch are contained in the malted barley used as the enzyme for the hydrolysis reaction. The first enzyme $\alpha$ - amylase is activated at $40-50{ }^{\circ} \mathrm{C}$ for a period of $1 \mathrm{~h}$. After $1 \mathrm{~h}$, the second enzyme $\beta$-amylase is activated at $65-70{ }^{\circ} \mathrm{C}$ and later the third enzyme glucoamylase (glucosidase) at the same temperature. The results indicate that the third enzyme is not activated until after $2 \frac{1}{2} \mathrm{~h}$ reaction time, which could account for the lower yields of reducing sugar obtained at these reaction times $\left(1 \frac{1}{2}-2 \frac{1}{2} h\right)$. The water content- dependence of starch for hydrolysis as observed in this study can be attributed to the origin and nature of starches. The biological origin of starch serves as a determining factor in the granules shape, size and morphology. As a result, these characteristics not only help to differentiate between various starches but also give an indication of the processing parameters. Moisture sorption by starch has been attributed to the interaction between the hydroxyl groups of the hexose moiety and water molecules ${ }^{15}$. Although water molecules form hydrogen bonds to both amylose and amylopectin, the amylopetin structures have been shown to physically trap water molecules. Relative humidity is another factor in the sorption profile of starches. Once available sites are saturated at low humidity, the specific surface which should be relatively higher does not contribute to moisture sorption. The sorption process at high humidity is reduced to condensation of water molecules over the already existing molecules forming layers that have decreased interaction with the surface ${ }^{16}$. This principle may explain the reason why at certain water contents, reducing sugar yields reduced. The water uptake of the starches at those water contents may be saturated and further increase in water content then leads to condensation of water molecules subsequently leading to decrease in interaction and reactions. 


\section{Conclusion}

The study has shown the effect of hydrolysis reaction time on the reducing sugar yield for acha and finger millet. General results show that both feed stock had good reducing sugar yield, however the reducing sugar yield obtained for acha was significantly higher than that for finger millet and therefore, acha would be the preferred feedstock for the purpose of choice.

\section{References}

1. Bryner M and Scott A, Chem Week, 2006, 168, 17-21.

2. Porteres R, Origins of African Plant Domestication, Harlan J R, de Wet J M J and Dogget A B H. Small millets-A selective review, The $1^{\text {st }}$ International small millets workshop, Bangalore, India, Oct. 29 - Nov. 21986.

3. Irving D W and Jideani I A, Cereal Chem., 1997, 74(3), 224-228; DOI:10.1094/CCHEM.1997.74.3.224

4. Morales Payan J P, Ortiz J R, Cicero J and Taveras F, Digitaria exilis as a crop in the Dominican Republic, In Trends in New Crops and New Uses Janick J and Whipkey A (Eds)., ASHS Press, Alexandria, 2003, V. A. P $\mathrm{S}_{1}-\mathrm{S}_{3}$.

5. Wikipedia. Eleusine coracana, http://en.wikipedia.org/wiki/Eleusine_coracana, Retrieved on 15 January 2015

6. Shiihii S U, Musa H, Bhatia P G and Emeje M, Nig J Pharm Sci., 2011, 10(1), 91-102.

7. Reddy L V A and Reddy O V S, Process Biochem., 2006, 41(3), 726-729; DOI:10.1016/j.procbio.2005.08.011

8. Anthony U, Sripriya G and Chandra T S, J Agric Food Chem., 1996, 44(9), 26162618; DOI:10.1021/jf950787q

9. Takeda C, Takeda Y and Hizukuri S, Cereal Chem., 1983, 60, 212-216.

10. AOAC. Official methods of Analysis. Association of Analytical Chemists, $14^{\text {th }}$ Ed., Washington, USA. 2010, 22209.

11. Pearson D. The Chemical Analysis of Foods; $7^{\text {th }}$ Ed., Churchill Livingston. New York, 1976, 11- 12, 14 - 15.

12. Plumer D T, Introduction to Practical Biochemistry, $2^{\text {nd }}$ Edition. Mc Graw Hill Book Co. UK Ltd., 1971, 57 - 58, 254 - 255.

13. Novellie L and Schütte R J, J Sci Food Agric., 1961, 12(8), 552-559; DOI:10.1002/jsfa.2740120804

14. Sair L and Fetzer W R, Ind Eng Chem., 1944, 36(3), 205-208; DOI:10.1021/ie50411a004

15. Manek R V, Kunle O O, Emeje M O, Builders P, Rama Rao G V, Lopez G P and Kolling W M, Starch/Stärke, 2005, 57(2), 55-61; DOI:10.1002/star.200400341 